\title{
Upending Climate Violence Research: Fossil Fuel Corporations and the Structural Violence of Climate Change
}

\author{
Eric Bonds \\ Department of Sociology and Anthropology \\ University of Mary Washington, Virginia, United States
}

\section{Abstract}

There is a high-profile body of work asserting a link between anthropogenic climate change and increased rates of violence. There is also an expanding literature that is highly skeptical of this research. Critics point out that (1) this research has so far produced widely divergent findings, and that there is no consensus on a causal link between climate and the incidence of conflict. Critics also argue that much climate violence research (2) draws upon a longdiscredited environmental determinism, (3) rehashes colonial stereotypes of the global South, (4) naturalizes and depoliticizes inequalities within and between nations, and (5) potentially creates new rationales for militarism and intervention from more powerful states. In the following essay, I build on these critiques, arguing that orthodox climate conflict research also focuses unduly on the potential climate-related violence of the poor, overlooking the violence of the powerful. Drawing from a climate justice perspective, I advocate for more study on the structural violence of climate change. To make this case, I focus on the world's largest publicly traded fossil fuel companies.

Keywords: climate conflict, climate justice, fossil fuel corporations, fossil fuel divestment, structural violence

\section{Introduction}

Will climate change make the world a more violent place? This is one of the more important questions of our time. There are a growing number of warnings coming from influential places about the relationship between climate change and violence. The United States government, for instance, has increasingly labeled global warming a "threat multiplier" (Banusiewicz, 2014; CNA, 2007).

$1 \quad$ Author contact: ebonds@umw.edu. 
Additionally, prominent journalists and policy analysts at important think tanks and advocacy groups have worked to highlight potential connections between global warming and conflict (see for instance EJF, 2014; Friedman, 2013; Werrell \& Fernia, 2013). And headlines at major newspapers, for example in the Washington Post, report "there's a surprisingly strong link between climate change and violence" (Mooney, 2014).

But how we answer the question- "will climate change create a more violent future?" - has much to do with the definitions we use. On one hand, the jury is very much out in terms of proving a causal relationship between climate change and increasing conflict. While some research, published in some of the world's most prestigious journals, has found what the authors describe as a strong link between climatic changes and rates of violence (see Burke et al., 2009; Hsiang et al., 2013), other research, sometimes published in the same journals, has found no such correlation (Buhaug, 2010a, 2010b; Wischnath \& Buhaug, 2014). There is, in fact, no consensus among quantitative researchers about the existence of a causal link between changes in temperature and rainfall and increasing violence (Buhaug, 2015; Selby, 2014). As the body of research on a potential climate violence relationship has grown, so too has the number of its critics.

An increasing number of authors worry that quantitative climate conflict research, as the next reincarnation of a long-discredited environmental determinism, is simply old wine in a new bottle (Hartmann, 2014; Raleigh et al., 2014). Moreover, according to critics, this research draws upon colonial stereotypes of the global South, implying that its peoples are somehow more predisposed to violence than those of European ancestry (Livingstone, 2015; Raleigh et al., 2014; Selby, 2014; Verhoeven, 2014). Finally, this research implies that the violence of poor people in the most peripheral areas of the global economy is "natural," hiding from view the ways that histories of colonialism and the contemporary global political economy have conditioned and produced violent conflict (Hartmann, 2010, 2014; Verhoeven, 2011, 2014). Why, given all these problems, has orthodox climate conflict research continued to flourish, and to enjoy such a high public profile? Critics warn that this is because the perspective so closely matches, and is so useful to, governments that are securitizing the issue of climate change and using it as a means to legitimate militarism and ongoing interventions in the global South (Hartmann, 2010, 2014; Selby, 2014; Verhoeven, 2014).

Given all the problems with orthodox climate violence research, does this mean that it is safe to say that climate change will not make the world a more violent place? Hardly. I advance instead that anthropogenic climate change is itself a kind of violence (Solnit, 2014). After all, it will certainly cause early deaths and it will drive people from their homes and homelands, all of which will cause untold suffering. Drawing upon a climate justice perspective, I provide here a brief overview of orthodox climate conflict research and further describe its 
critics' concerns. I add to their critique by arguing that this body of research, as a whole, focuses almost exclusively on the potential violence of the poor, overlooking the violence of the wealthy and powerful groups who benefit most from, and actively work to sustain, a fossil fuel-dependent neoliberal capitalism. To begin amending this bias in the climate violence literature, I draw upon work in sociology, green criminology, and geography to argue that major fossil fuel companies are disproportionately responsible for, and have disproportionately benefited from, the structural violence of climate change.

\section{Orthodox climate violence research and its critics}

There is a long line of argumentation in social/environmental research, going back to Malthus (1798), making a link between environmental scarcity and violent conflict. Many contemporary investigators looking at climate change are doing work that is largely in alignment with this long-standing research trend. The argument is basically that climate change will act as a stressor in the larger environment that, along with other important conditions, will make large-scale violence more likely. It is important to note that most analysts are not alleging that there is a direct causal relationship between climate change and violence, but that climate change is an important background force that heightens other risk factors associated with conflict (Homer-Dixon, 1999). Some studies in this body of research simply try to make the point that the relationship exists, without going into depth to examine particular causal mechanisms (Burke et al., 2014; Hsiang et al., 2013).

Other studies try to look deeper into potential causal factors, arguing that weather aberrations - such as prolonged dry seasons, droughts, abnormally high temperatures, or excessive rainfall - are associated with increased levels of conflict (Burke et al., 2009; Hendrix \& Saleyhan, 2012; Hsiang et al., 2011; Kelley et al., 2015; Landis, 2012; Raleigh \& Kniveton, 2012). Such weather abnormalities, according to these researchers' arguments, are consistent with climate change models and could become the "new normal" in years ahead. These changes in the weather might drive conflict, they explain, by negatively impacting crop production and reducing food availability, thereby triggering migration or catalyzing resentments against governments or other ethnic groups. Or in another line of thinking, researchers argue that unusually hot and dry weather associated with climate change could drive pastoralists out of their traditional homelands and into conflict over land and water resources with agricultural communities. 
While a large number of studies posit a link between climate change and violence, there is by no means a consensus among researchers. For one, several notable studies find little-to-no support for the relationship when other standard predictors for the onset of violence are factored in, such as (1) levels of economic development, (2) ethno-political exclusion practiced by governments, (3) time period (for instance, accounting for the end of the Cold War), and (4) levels of conflict in nearby countries (Buhaug, 2010a; Wischnath \& Buhaug, 2014). Other studies find a limited relationship between weather and conflict, but it is very weak compared to those associated with more conventional variables (Klomp \& Bulte, 2013; O'Loughlin et al., 2014).

In fact, some research finds the opposite. Gartzke (2012, p. 177) analyzed global temperature trends in relation to rates of conflict over the past 200 years and found that "global warming is associated with a reduction in interstate conflict." Humans have, after all, been warming the climate since the beginning of the Industrial Revolution, but during this time per capita rates of violence have been declining (see Pinker, 2011). Of course, Gartzke does not actually believe that a warming planet necessarily increases harmony between nations, but rather that industrialization - achieved by burning fossil fuels and inadvertently warming the planet - has brought about greater prosperity and a decreasing tendency for governments to go to war. Buhaug (2010b) comes to a similar conclusion when comparing the increasing temperature trends in Africa over the past 30 years in relation to the diminishing frequency of both large and small civil wars (in which the numbers of fatalities have also been diminishing).

These findings illustrate that there is no clear consensus that a relationship exists between climate change and rates of violence, as both Buhaug (2015) and Selby (2014) confirm in separate reviews of the literature. To Buhaug (2015, p. 269), this has much to do with the fact that "climate and conflict are not connected in the simple and direct manner as sometimes portrayed," and that therefore climate conflict researchers need to do a better job of attending to how political and economic forces mitigate or increase climate vulnerability (see also Raleigh, 2010). Buhaug also explains that the widely divergent, and often contradictory, findings in orthodox climate violence research are often caused by analysts' tendency to universalize potential variables, neglecting for instance how changes in rainfall or temperature patterns could have very different effects depending upon the geography and political economy of particular regions. Similarly, Raleigh and her co-authors (2014, p. 76) point out that orthodox climate violence researchers often fail to specify what exactly constitutes conflict in the first place, writing that, "if the social setting that engenders conflict is ignored, there is also danger that multiple types of conflict become conflated. Conflict in wealthy areas can be reduced to the level of baseball skirmishes instead of large-scale societal violence." While Buhaug (2015) and others think 
that orthodox climate violence research can be rescued by better use of theory and more fine-grained analysis, other critics argue that its problems run much deeper, and that looking at climate variability as a potential driver of conflict is a project that is best abandoned.

As one of these critics, Hartmann (2010, p. 237) argues that "a certain exceptionalism is at work" in much orthodox climate conflict research, in which "it is commonly assumed that scarcity can lead to institutional and technological innovation in more affluent countries, [while] just the opposite is assumed for poor people in less affluent countries." In this research narrative, according to Hartmann, scarcity renders people in poorer nations "into victims/villains, incapable of innovation or livelihood diversification and naturally prone to violence" (ibid.). Contrary to the orthodox climate violence narrative, Raleigh and her colleagues (2014, p. 77) write that the reality is typically quite the opposite. "People in poor countries do not respond to bad weather by attacking each other," they contend. Rather, "on the ground in developing countries, climate change and ecological stress is treated as a problem to be solved, not a harbinger of apocalyptic violence" (ibid.). To these critics, this "research programme reflects and reproduces an ensemble of Northern stereotypes, ideologies and policy agendas" (Selby, 2014, p. 830).

Livingstone (2015) finds that such notions are not new. He looked back to the historical origins of today's orthodox climate violence research and found that there are very old Northern ideas that people in more southerly latitudes are more predisposed to violence. This discourse, of course, is rooted in histories of racism and colonialism. And it was a very useful discourse indeed to colonial authorities who had to legitimate their undemocratic rule of foreign lands (Verhoeven, 2014). Similarly, according to critics, orthodox climate violence research is ideologically useful today because it tends to gloss over or hide how histories of colonialism, along with the operation of the contemporary global political economy, have created tremendous global inequalities and made some people much more vulnerable to the impacts of climate change. According to Verhoeven (2011, p. 685), orthodox climate violence research:

Essentially absolves political actors from their responsibility in creating and sustaining the conditions that make people vulnerable to crises. It ignores the fact that a drought might push communities over the edge, but isn't a real cause ... it only triggers the final stage of a complex, drawn-out process of violent marginalization that benefits local, national and/or global elites.

In consequence, orthodox climate violence research depoliticizes global inequalities and their resulting climate vulnerabilities, making the potential violence of actors in the global South seem "natural" (Raleigh et al., 2014; Selby, 2014; Verhoeven, 2014). 
But, according to critics, the orthodox climate violence narrative has other ideological implications. Hartmann (2014, p. 775), for instance, worries that the "depiction of Africa as a continent under severe demographic, climate and security stresses helps to legitimise the intensification of monitoring and surveillance by the US intelligence community." Hartmann also warns that the discourse could be used as a means to further militarize United States foreign aid. Moreover, the prospect of ever-unfolding disasters and climate strife in the global South could be used as a rationale among more powerful nations in the global North to continue, or even increase, their high rates of spending on military equipment, rather than spending more money on climate mitigation to actually get at the root of the problem (Bonds, 2015).

Taken as a whole, then, while orthodox climate violence research is a growing area of study that has attracted a great deal of public attention, it has also been greeted by a growing number of critics who claim that it is beset by methodological, epistemological, and political/ethical problems. Beyond outlining these criticisms, the goal of this essay is to add one more concern: while orthodox climate violence research focuses on the potential violence of those in the global South whose lives will be most harmed by climate change, it overlooks the potentially climate-related violence of the powerful. If a speedy transition to a less carbon-intensive economy could slow rates of global warming, which would have the ultimate effect of saving lives and reducing the extent of climatic displacement, are deliberate efforts to prevent or slow this transition a kind of violence? Maintaining our current rates of emissions, after all, threatens human communities across the world. While orthodox climate violence research does not ask such questions, a climate justice perspective, drawing on the concept of structural violence, insists that we should.

\section{The structural violence of climate change}

Martin Luther King Jr. stated in a sermon he delivered in 1956 that "peace is not merely the absence of some negative force - war, tension, confusion, but it is the presence of some positive force-justice" (King, 1956). Both before and since King made this eloquent statement, philosophers and social activists have critiqued narrow conceptualizations of peace as the lack of armed hostilities and active fighting. Narrow definitions of peace, after all, overlook other more prevalent causes of death and suffering in the world. Johan Galtung (1969) brought this critique into the social sciences in a now classic essay in which he introduced the concept of "structural violence," which he defined as the existence of suffering and death in the world that might otherwise be prevented. Structural violence, he argues, is caused when "resources are unevenly distributed, as when income distributions are heavily skewed, literacy/education unevenly distributed, 
medical services existent in some districts and for some groups only, and so on" (Galtung, 1969, p. 171). As Soron (2007) further explains, it is "the normal, unexceptional, anonymous, and often unscrutinized violence woven into the routine workings of prevailing power structures."

While death is inevitable and suffering for all people who live long enough is unavoidable, Galtung (1969, p. 168) focuses on preventable deaths and degrees of suffering as manifestations of structural inequalities, writing that, for instance, "if a person died from tuberculosis in the eighteenth century it would be hard to conceive of this as violence since it might have been quite unavoidable, but if he dies from it today, despite all the medical resources in the world, then violence is present according to our definition." Anthropologist and medical doctor Paul Farmer has put the concept to good use to study the tuberculosis and HIV/AIDS epidemics that needlessly kill millions of persons every year. Farmer's (2003, 2004) own focus is on Haiti, and the ways that its historical domination within the global political economy and its own internal inequalities - based on divisions of race, class, and gender - create a society that is ravaged by these diseases, which could be largely averted or at least made much less severe.

Both Galtung and Farmer insist that social scientists are introducing an important kind of bias in their research by focusing only on forms of violence that are intentionally and directly carried out. Certainly direct forms of violence are more immediately visible. Warfare, with its bombs and explosions and all the terrible wounds it creates, is often spectacular. It embodies a certain kind of drama that often draws and holds our attention (Galtung, 1969). Even so, both theorists warn that narrowly focusing on dramatic forms of direct violence will let the biggest killers in contemporary global society go free, and mostly unnoticed.

Typically, orthodox climate conflict research measures violence in terms of the numbers of persons killed in hostilities. There is no doubt that such killings are troubling, and any connection between climate change and the onset of violent clashes in the global South should be studied. But the almost exclusive focus on this potential connection in regard to climate-related violence is also disconcerting. After all, can we say that, if global warming continues unabated, the increasing numbers of children who will die from waterborne diseases is somehow peaceful, even if it does not trigger armed combat? Can we say that the millions of persons who will be forced to leave their homes and homelands due to rising ocean levels are going in peace, even if their migrations do not lead to war? And what about the growing rates of people expected to be killed or displaced by the increasing numbers of severe tropical storms? While they might suffer silently without raising arms, is this peace? Clearly not. But current 
research on climate-related violence is unmindful of the likelihood of such suffering and death. It misses the mark by failing to acknowledge that climate change is itself violent (Solnit, 2014).

Dennis Soron (2007), for one, has advocated for the study of the structural violence of climate change. Such violence is not committed with malice and intent. And its impacts will not be felt immediately, but only over the decades to come. The World Health Organization, for instance, predicts that 250,000 excess deaths per year will be indirectly caused by climate change between the years 2030 and 2050 (through, for example, increased childhood malnutrition, heat waves, and the spread of tropical diseases) (Hales et al., 2014). Obviously, these deaths will pale in comparison to those that will be linked to climate change beyond 2050 if current rates of warming continue. And, needless to say, the bulk of these deaths will be experienced in the global South, among groups who contributed least to global warming but are also most vulnerable to its effects (Parr, 2014; Roberts \& Parks, 2006).

To Soron (2007), the structural violence of climate change is created by the normal operation of global capitalism, in which corporate profits and economic growth have been prioritized over environmental well-being and justice (see also Klein, 2014; Lynch et al., 2013; Parr, 2014). For this reason, Soron (2007) argues:

Responding effectively to the structural violence of climate change will require a correspondingly structural program of social change, oriented not simply towards technological fixes, but towards achieving a greater degree of democratic control over economic life, refitting the scale of production and consumption to respect environmental limits.

There is a large body of work within both environmental sociology and green criminology that supports Soron's approach: the inequalities necessarily part of capitalism and its emphasis upon economic growth regardless of environmental consequences mean that it is an unsustainable system that is imperiling whole ecosystems and entire human communities (see Foster, 2002; Gould et al., 2008; Lynch et al., 2013; Stretesky et al., 2013). At the same time, the climate crisis requires immediate action, and meaningful carbon reductions could technically be possible even within the social organization of capitalism (Parenti, 2013). For this reason, it is important to look for potential opportunities to intervene within this system to push it toward less carbon dependency.

Downey and Strife (2010) provide some important insights on how this goal might be achieved. While capitalism as a whole is unsustainable, they also explain that certain groups and institutions benefit disproportionately from environmentally degrading behaviors (e.g., resource extraction, the production of toxic pollution and carbon emissions). Downey and Strife therefore argue that social scientists should study how these groups and institutions organize 
themselves within capitalism to protect and promote their ability to profit from environmental degradation. Following their lead, I apply the concept of structural violence to large publicly traded corporations in the next section. While I acknowledge that capitalism itself produces structural violence through climate change and other environmental harms, I also make the case that these large corporations disproportionately benefit from, and are disproportionately responsible for, our contemporary inability to achieve more significant carbon reductions.

\section{Structural violence and fossil fuel corporations}

Social sustainability science is typically the result of cross-pollination between environmental justice movements and academics, as each group draws upon and elaborates ideas and strategies used by the other (Martinez-Alier et al., 2014). Climate justice activists, earth scientists, and, most unexpectedly, financial analysts have similarly co-developed a shared way of understanding the perilous nature of our climate's future and the difficulties humanity faces in achieving a political solution to the crisis of climate change. Central here are the carbon reserves held by the world's largest fossil fuel companies, along with the political power that they wield.

In 2009, Malte Meinshausen and his colleagues published an article in the prestigious journal Nature that attempted to calculate a "carbon budget" based upon the international consensus that global atmospheric temperatures should be kept below 2 degrees Celsius of warming. While, the authors noted, this is not a "safe" level of warming because it will still create profound impacts on ecosystems and human communities, it nonetheless had "gained increasing prominence in science and policy circles as a goal to prevent dangerous climate change" (Meinshausen et al., 2009, p. 1159). Based on extensive climate modeling, the authors determined that human societies have only a limited ceiling on the gigatons of carbon that they can emit into the atmosphere without soon exceeding the 2 degrees of warming level. In fact, at current rates of emissions, these researchers determined that we are well on our way to exceed these levels within the next few decades. Most importantly, these scientists also ran models that included the potential emissions from economically viable reserves in oil, gas, and coal around the world. They found that emissions from burning these underground reserves would "vastly exceed the allowable $\mathrm{CO}_{2}$ emission budget for staying below $2{ }^{\circ} \mathrm{C}^{\prime \prime}$ (ibid., p. 1160).

The paper gained a great deal of attention among climate scientists, but was also popularized outside academic audiences when its findings were discussed in the International Energy Agency's World Energy Outlook 2009 report, which 
summed up the findings by stating that "we are currently eating into these $\mathrm{CO}_{2}$ budgets at a disproportionate rate" (IEA, 2009, p. 193). A main reason for the delay in bringing carbon emissions in line with the internationally agreed upon carbon budget is, according to the IEA report, capital that is sunk into carbon-intensive technologies, effectively "locking in" companies to highcarbon futures.

A group of environmentally minded financial analysts at Carbon Tracker grabbed hold of this perspective in 2011. They scoured public records to determine the size of the proven oil, gas, and coal reserves claimed by the world's largest publicly traded fossil fuel corporations. They then calculated the carbon equivalents of the reserves held by the 200 largest of these companies. The researchers found that these companies alone held five times more carbon in their reserves than could be emitted without pushing beyond the "carbon budget" that would keep warming below 2 degrees Celsius. The Carbon Tracker report concluded therefore that at least $80 \%$ of these fossil fuels are "unburnable carbon," or that they are at least unburnable if governments hope to keep warming below catastrophic levels (Leaton, 2011). As financial specialists, the analysts were therefore concerned that contemporary financial markets have a "carbon bubble" because they accord value to energy companies based on reported fossil fuel reserves that must be left in the ground, rendering them valueless or at least worth far less than that which the market currently accords them.

Climate leader Bill McKibben drew attention to this report, however, as a means to both understand the dynamics of our environmental crisis and to propose a citizens' movement that could push for solutions. In his widely read 2012 article in Rolling Stone, McKibben argued that coal, oil, and gas companies have a business model that commits them to bringing all the world's fossil fuels onto the market, which will result in the production of carbon emissions that will radically transform the climate and threaten human existence. And while these publicly traded companies already claim ownership of fossil fuel reserves that far exceed the world's carbon budget, these companies' business model also brings them into partnerships with governments - such as Saudi Arabia, Iraq, and Iran - that hold even greater reserves of fossil fuels.

To McKibben (2012), these are businesses whose activities are incompatible with life as we know it on Earth. Despite a decades-old scientific consensus on anthropogenic global warming, the world's largest fossil fuel companies are nonetheless committed to a business model of unrestrained, or only weakly restrained, fossil fuel extraction and combustion. Their profitably depends upon it. They have sunk capital into exploration and into the development of their fossil fuel reserves. And their shareholder value would plummet if they were forced to leave much of their carbon reserves underground. Consequently, they 
are fighting to protect their continued ability to transform the climate, which their business model demands, in ways that will result in profound, and otherwise avoidable, human suffering. In so doing, major fossil fuel companies are disproportionately contributing to the structural violence of climate change.

According to the Intergovernmental Panel on Climate Change (IPCC, 2014), pushing beyond 2 degrees Celsius of warming creates "considerable" risk that people will die, be injured, or have their livelihoods disrupted due to increasing coastal and inland flooding. Likewise, there are considerable risks of "extreme weather events leading to breakdown of infrastructure networks and critical services such as electricity, water supply, and health and emergency services" (ibid., p. 13). Moreover, food insecurity is predicted to increase, along with death and sickness from increasing periods of extreme heat. While such impacts will happen even by keeping within the 2 degrees Celsius threshold, they will become more extensive as the atmosphere is warmed beyond this level. To put this more bluntly, the lives of hundreds of millions of people - in some cases whole societies - will be impacted.

Despite these consequences, major fossil fuel companies are fighting hard to preserve their business model, and have exerted considerable political influence to defeat or weaken efforts to limit carbon emissions around the world. Within the United States alone, oil, gas, and coal mining companies spent more than US\$141 million on lobbying to influence Congress and federal agencies in 2014, which works out to more than US\$386,000 per day, according to the Center for Responsive Politics (2016). This figure does not include the federal lobbying of electricity utilities, which in the United States have also vigorously opposed carbon emission limits. This figure also leaves out the vast amounts of money these companies have paid to promote oil, gas, and coal extraction at the state level of government.

Beyond lobbying to fight carbon emissions, large oil, gas, and coal companies are major campaign contributors to United States elections. The Center for Responsive Politics estimates that these companies gave close to US\$74 million to bankroll the campaigns of political candidates in the 2014 election. Clearly, large fossil fuel companies give contributions for a number of reasons. An empirical investigation by Long et al. (2012) for instance finds that coal companies increase political donations to weaken or avoid enforcement of environmental laws. It also stands to reason that they spend large sums to decrease political support for climate change legislation. This would certainly go a long way to help explain the United States Congress's recalcitrance on the issue, despite public support for steeper emissions reductions. 
Importantly, lobbying and campaign finance also help secure tens of billions of dollars in subsidies every year for major fossil fuel companies. To be exact, governments around the world spent a total of US\$88 billion to subsidize exploration for new oil, gas, and coal reserves in 2013 (Bast et al., 2014). But this is only a portion of the total amount of capital that fossil fuel companies invest to search out new reserves. In 2012 alone, the world's largest 200 fossil fuel companies spent US\$674 billion to hunt for new sources of oil, gas, and coal (Carbon Tracker, 2013). In other words, even as the largest fossil fuel companies in the world possess more than enough carbon underground to push atmospheric temperatures far beyond 2 degrees Celsius - which will result in death, displacement, and suffering - they are making huge investments to find yet more reserves.

In addition to lobbying and providing campaign contributions to help defeat or weaken climate change legislation, fossil fuel companies and their individual owners/shareholders have played a major role in funding think tank-driven climate change denialism. In the United States, think tanks have mounted yearslong campaigns to convince the public that the science on global warming is unsettled or wrong (Freudenburg et al., 2008; Jacques et al., 2008; McCright \& Dunlap, 2000). Elite-drive climate denialists further argue that, even if the science is correct, efforts to reduce carbon emissions would do more harm than good in terms of economic well-being (McCright \& Dunlap, 2000). Climate change denialism has had the effect of "institutionalizing delay" on climate change mitigation by effectively polarizing the issue of climate change and by giving elected officials the political cover they need to vote against emissionreduction legislation (Brulle, 2014; McCright \& Dunlap, 2011).

In summary then, major oil, gas, and coal corporations have played, and continue to play, a critical role in the unfolding crisis of climate change by both extracting and selling the fossil fuels that are driving global warming, but also by successfully working to defeat or water down public efforts to reduce fossil fuel dependency. Because this behavior will contribute to the deaths, displacement, and untold suffering climate change will ultimately cause, it can be seen as a form of structural violence. Of course, none of this is to say that major publicly traded fossil fuel companies are the only powerful organizations responsible for the structural violence of climate change. For instance, stateowned oil, gas, and coal companies - such as Saudi Aramco and major Chinesecontrolled coal enterprises - and the governments of wealthy nations that are leading producers of fossil fuels - like Saudi Arabia, Canada, the United States, and Australia - play a role in contributing to climate violence as well (see for instance Mulvaney et al., 2015). 
In making the link to structural violence, I also want to stress that large publicly traded fossil fuel companies are not intentionally working to cause harm and suffering. In fact, given the prevailing legal, political, and economic structure of neoliberal capitalism, it would be extremely difficult - if not impossible - for them to act otherwise. These companies' efforts to extract the fullest amount of fossil fuels that technological and market conditions will allow is economically rational, at least in the short term. If any large oil, gas, or coal company failed to do so, it would, after all, be outcompeted by other companies in cut-throat global markets. And given that it is legal to fund elections in order to influence law-making, in this case to defeat or weaken climate change legislation, it again is rational for these companies to take advantage of such opportunities. Clearly then, these companies have limited agency within the prevailing political economy. Getting different outcomes will require systemic changes. But this is a very large goal, and it is difficult to know where to begin.

One starting place is to simply point out the ways that fossil fuel companies have disproportionately benefited from a carbon-intensive capitalism, and how they have led the largely effective opposition against efforts to diminish fossil fuel dependency. The overall point is that responsibility for the structural violence of climate change is not shared evenly. Unveiling the climate violence of powerful organizations, like major fossil fuel corporations, is important in order to counter biases in orthodox climate violence research. More importantly, it might have some resonance in larger political debates.

\section{Politics, social science, and climate violence}

There is a long-standing bias in the social sciences: the violence of the poor is subjected to intense scrutiny, while the violence of the powerful often evades attention. For example, it is well known to criminologists that white-collar crime - including corporate crime - is just as costly, in terms of financial losses and losses in human lives, as the crimes of the poor, but it receives only a tiny fraction of researchers' attention (Stretesky et al., 2013). Likewise, in making a case for a new green criminology, Lynch and his co-authors (2013, p. 998) write that, "green harm and [environmental] crime are more widespread, have more victims and produce more damage than crimes that 'occur on the streets'." Even so, green crime has been largely neglected by most criminologists. And scholars of state crime similarly point out that when governments make decisions to violate international laws in the process of invading other nations, such as the United States's decision to invade Iraq in 2003, it results in the deaths of thousands of people and imposes heavy costs on public treasuries (Kramer et al., 2005). But again, for the most part state crime goes relatively understudied compared to the violence of the poor (see Rothe, 2009). 
These kinds of biases mean that the social sciences often misread the world. Conversely, focusing greater attention on the violence of the powerful would produce a social science that is more reflective of the most prevalent forms of harm in contemporary society. But more importantly, white-collar criminologists, state-crime criminologists, and green criminologists also point out that the biases of orthodox criminology have ideological implications: by focusing only on the poor, the harm caused by the very powerful goes mostly unnoticed, and is therefore more easily reproduced. These radical criminologists are, in other words, trying to flip the script in traditional social science to work for a more sustainable and peaceful future (Lynch et al., 2013).

Similarly, I have argued for the need to upend climate violence research. While orthodox climate conflict researchers have produced a high-profile literature that links climate change with increased violence in the global South, there is also a growing body of work that challenges such claims. Critics have conducted their own empirical tests, casting doubt on any strong climate change/conflict relationship. Critics also argue that orthodox climate violence researchers rely on a long-discredited environmental determinism, which largely reproduces colonial stereotypes about the ways that warmer climates supposedly influence behavior. According to critics, this research perspective is also ideological in its effect, as it "naturalizes" conflict in the global South while giving governments in the global North new justifications for militarism and foreign surveillance. I add to these criticisms by arguing that traditional climate violence research unduly focuses on the potential violence of the poor (those most vulnerable to global warming impacts) while ignoring the violence of powerful organizations that disproportionately benefit from, and have disproportionately sought to preserve, a carbon-dependent economy.

The world's largest publicly traded fossil fuel companies have more than enough carbon reserves to push the climate into extremely dangerous levels of warming. These companies nonetheless remain committed to extracting their reserves, and are influencing public policy in order to protect their ability to do so. While fossil fuel companies are spending large amounts of money to influence politics, they are spending even larger sums on exploration in order to find yet more carbon reserves to add to those they already hold.

Ultimately, the consequences of this situation will be felt through rising sea levels, increasingly severe storms, heat waves, and droughts, all of which will harm people and cause suffering. As such, it constitutes a kind of violence, albeit one that is not caused by malevolence, nor with intent. It is instead an unintended violence that will be increasingly felt over generations to come. Any sense of proportion insists that attention to the potential climate violence of the poor should not overshadow the preventable harm created through climate change itself. But attending to the structural violence of climate 
change is not purely a scholarly issue, and naming those organizations most responsible for global warming could help advance political campaigns to reduce carbon emissions.

A carbon divestment movement is mobilizing based on both awareness of the limited nature of the world's remaining "carbon budget" and awareness that publicly traded fossil fuel companies hold enough carbon reserves to far surpass this threshold and push Earth's climate into uncharted territory. Members of this movement are working to encourage their city governments, churches, and universities to pull their investments from the world's largest fossil fuel companies, and they have had some notable successes so far (see Divestment Commitments, 2015). Members of this movement understand full well that their strategy will not bankrupt these very large and very profitable corporations. Their strategy instead is to tarnish the public image of fossil fuel companies, and by so doing diminish their political power. If these companies are successfully stigmatized, so the hope goes, they may not have the same capacity to successfully push back on carbon emission limits and other needed environmental reforms. The strategy is imperfect, but many important environmental thinkers today argue that it is the best hope we have of creating the climate justice movement necessary to achieve a less disastrous environmental future. Naming the climate violence produced by these companies for what it is might further this cause, and might be one small contribution from the social sciences to the divestment movement.

The larger point is that, while the structural violence of global warming might be felt through changes in the weather, it is not like the weather itself, in the sense that it is outside human control. Researchers studying the potential climate-related violence of the poor often presume that, because a certain amount of climate change is "locked in" due to the carbon emissions already in the atmosphere, increasing conflict is inevitable. But this does not need to be the case. Governments and publics can respond to changing atmospheric conditions in numerous ways, some of which are more or less just, some of which are more or less likely to further enflame tensions in potential conflict zones. But just as importantly, governments and publics can put an end to the structural violence of climate change by moving to aggressively cut carbon emissions and by making the monumental investments in a green infrastructure necessary to achieve a less carbon-intensive economy. Naming the violence of climate change as such might be helpful in this difficult work ahead. 


\section{References}

Banusiewicz, J. D. (2014, October 13). Hagel to address "threat multiplier" of climate change. U.S. Department of Defense news article. Retrieved from www.defense.gov/news/newsarticle.aspx?id=123398.

Bast, E., Makhijani, S., Pickard, S., \& Whitley, S. (2014). The fossil fuel bailout: G20 subsidies for oil, gas and coal exploration. London and Washington, DC: Overseas Development Institute and Oil Change International.

Bonds, E. (2015). Challenging climate change's new "security threat" status. Peace Review: A Journal of Social Justice, 27, 209-216.

Brulle, R. J. (2014). Institutionalizing delay: Foundation funding and the creation of US climate change counter-movement organizations. Climate Change, 122, 681-694.

Buhaug, H. (2010a). Climate not to blame for African civil wars. Proceedings of the National Academy of Sciences, 107(38), 16477-16482.

Buhaug, H. (2010b). Reply to Burke et al.: Bias and climate war research. Proceedings of the National Academy of Sciences, 107(51), E186-E187.

Buhaug, H. (2015). Climate-conflict research: Some reflections on the way forward. WIREs Climate Change, 6(3), 269-275.

Burke, M., Hsiang, S. M., \& Miguel, E. (2014). Climate and conflict. National Bureau of Economic Research Working Paper No. 20598. Retrieved from www.nber.org/papers/w20598.

Burke, M. B., Miguel, E., Satyanath, S., Dykema, J. A., \& Lobell, D. A. (2009). Warming increases the risk of civil war in Africa. Proceedings of the National Academy of Sciences, 49, 20670-20674.

Carbon Tracker. (2013). Unburnable carbon 2013: Wasted capital and stranded assets. London: Carbon Tracker \& Grantham Research Institute on Climate Change and the Environment. Retrieved from carbontracker.live.kiln.digital/ Unburnable-Carbon-2-Web-Version.pdf.

Center for Responsive Politics. (2016). Top industries [opensecrets.org webpage]. Retrieved from www.opensecrets.org/lobby/top.php?showYear= 2014\&indexType $=$ i.

CNA (Center for Naval Analysis). (2007). National security and the threat of climate change. Alexandria, VA: CNA Corporation. Retrieved from www.cna.org/CNA_files/pdf/National \%20Security $\% 20$ and $\% 20$ the $\% 20$ Threat $\% 20$ of $\% 20$ Climate $\% 20$ Change.pdf. 
Divestment Commitments. (2015). Fossil free [webpage]. Retrieved from gofossilfree.org/commitments/.

Downey, L., \& Strife, S. (2010). Inequality, democracy, and the environment. Organization \& Environment, 23(2), 155-188.

EJF (Environmental Justice Foundation). (2014). The gathering storm: Climate change, security, and conflict. London: EJF. Retrieved from www.ejfoundation. org/report/gathering-storm-climate-change-security-and-conflict.

Farmer, P. (2003). Pathologies of power: Health, human rights, and the new war on the poor. Berkley: University of California Press.

Farmer, P. (2004). An anthropology of structural violence. Current Anthropology, $45,305-325$.

Foster, J. B. (2002). Ecology against capitalism. New York: Monthly Review Press.

Freudenburg, W. R., Gramling, R., \& Davidson, D. J. (2008). Scientific certainty argumentation methods (SCAMs): Science and the politics of doubt. Sociological Inquiry, 78(1), 2-38.

Friedman, T. L. (2013, May 18) Without water, revolution. The New York Times. Retrieved from www.nytimes.com/2013/05/19/opinion/sunday/friedmanwithout-water-revolution.html?_r=0.

Galtung, J. (1969). Violence, peace, and peace research. Journal of Peace Research, 6(3), 167-191.

Gartzke, E. (2012). Could climate change precipitate peace? Journal of Peace Research, 49, 177-192.

Gould, K. A., Pellow, D. N., Schnaiberg, A. (2008). The treadmill of production: Injustice and unsustainability in the global economy. Boulder, CO: Paradigm.

Hales, S., Kovats, S., Lloyd, S., \& Campbell-Lendrum, D. (Eds.)(2014). Quantitative risk assessment of the effects of climate change on selected causes of death, $2030 \mathrm{~s}$ and 2050s. Geneva: World Health Organization. Retrieved from www.who. int/globalchange/publications/quantitative-risk-assessment/en/.

Hartmann, B. (2010). Rethinking climate refugees and climate conflict: Rhetoric, reality and the politics of policy discourse. Journal of International Development, 22(2), 233-246.

Hartmann, B. (2014). Converging on disaster: Climate security and the Malthusian anticipatory regime for Africa. Geopolitics, 19(4), 757-783. 
Hendrix, C. S., \& Saleyhan, I. (2012). Climate change, rainfall, and social conflict in Africa. Journal of Peace Research, 49, 35-50.

Homer-Dixon, T. F. (1999). Environment, scarcity, and violence. New Haven, CT: Princeton University Press.

Hsiang, S. M., Burke, M., \& Miguel, E. (2013). Quantifying the influence of climate on human conflict. Science, 341, 6151.

Hsiang, S. M., Meng, K. C., \& Cane, M. A. (2011). Civil conflicts are associated with the global climate. Nature, 476, 438-441.

IEA (International Energy Agency). (2009). World energy outlook 2009. Paris: IEA. Retrieved from www.iea.org/textbase/npsum/weo2009sum.pdf.

IPCC (Intergovernmental Panel on Climate Change). (2014). Summary for policymakers. In IPCC, Climate change 2014: Impacts, adaption, and vulnerability. Part A: Global and sectoral impacts. Contribution of working group II to the fifth assessment report of the Intergovernmental Panel on Climate Change. Cambridge: Cambridge University Press. Retrieved from ipcc-wg2. gov/AR5/images/uploads/WG2AR5_SPM_FINAL.pdf.

Jacques, P. J., Dunlap, R. E., \& Freeman, M. (2008). The organization of denial: Conservative think tanks and environmental skepticism. Environmental Politics, 17, 349-385.

Kelley, C. P., Mohtadi, S., Cane, M. A., Seager, R., \& Kushnir, Y. (2015). Climate change in the Fertile Crescent and implications of the recent Syrian drought. Proceedings of the National Academy of Sciences, 112(11), 3241-3246.

King, M. L., Jr. (1956). When peace becomes obnoxious. Sermon delivered on 18 March in Louisville, Kentucky. Retrieved from mlk-kpp01.stanford. edu/index.php/encyclopedia/documentsentry/when_peace_becomes_ obnoxious_sermon_delivered_on_18_march_1956.

Klein, N. (2014). This changes everything: Capitalism vs. the climate. New York: Simon \& Schuster.

Klomp, J., \& Bulte, E. (2013). Climate change, weather shocks, and violent conflict: A critical look at the evidence. Agricultural Economics, 44, 63-78.

Kramer, R., Michalowski, R., \& Rothe, D. (2005). "The supreme international crime:" How the U.S. invasion of Iraq threatens international law. Social Justice, 32, 52-81.

Landis, S. T. (2012). Temperature seasonality and violent conflict: The inconsistencies of a warming planet. Journal of Peace Research, 51, 603-618. 
Leaton, J. (2011). Unburnable carbon - Are the world's markets carrying a carbon bubble? London: Carbon Tracker. Retrieved from www.carbontracker.org/ wp-content/uploads/2014/09/Unburnable-Carbon-Full-rev2-1.pdf.

Livingstone, D. N. (2015). The climate of war: Violence, warfare, and climate reductionism. WIREs Climate Change, 6(5), 437-444.

Long, M. A., Stretesky, P. B., Lynch, M. J., \& Fenwick, E. (2012). Crime in the coal industry: Implications for green criminology and treadmill of production. Organization \& Environment, 25, 328-346.

Lynch, M. J., Long, M. A., Barrett, K. L., \& Stretesky, P. B. (2013). Is it a crime to produce ecological disorganization? Why green criminology and political economy matter in the analysis of global ecological harms. British Journal of Criminology, 53(6), 997-1016.

Malthus, T. R. (1798). An essay on the principle of population as it affects the future improvement of society. London: J. Johnson.

Martinez-Alier, J., Anguelovski, I., Bond, P., Del Bene, D., Demaria, F., Gerber, J.-F., ... Yánez, I. (2014). Between activism and science: Grassroots concepts for sustainability coined by environmental justice organizations. Journal of Political Ecology, 21, 19-60.

McCright, A. M., \& Dunlap, R. E. (2000). Challenging global warming as a social problem: An analysis of the conservative movement's counter-claims. Social Problems, 47, 499-522.

McCright, A. M., \& Dunlap, R. E. (2011). The politicization of climate change and polarization in the American public's views of global warming, 20012010. The Sociological Quarterly, 52, 155-194.

McKibben, B. (2012, July 19). Global warming's terrifying new math. Rolling Stone weblog post. Retrieved from www.rollingstone.com/politics/news/ global-warmings-terrifying-new-math-20120719.

Meinshausen, M., Meinshausen, N., Hare, W., Raper, S. C., Frieler, K., Knutti, R., .. Allen, M. R. (2009). Greenhouse-gas emission targets for limiting global warming to $2{ }^{\circ} \mathrm{C}$. Nature, $458(7242), 1158-1162$.

Mooney, C. (2014, October 22). There's a surprisingly strong link between climate change and violence. The Washington Post. Retrieved from www. washingtonpost.com/blogs/wonkblog/wp/2014/10/22/the-surprisinglystrong-link-between-climate-change-and-violence/. 
Mulvaney, D., Gershenson, A., \& Toscher, B. (2015). The potential greenhouse gas emissions from U.S. federal fossil fuels. Ecoshift Consulting and Center for Biological Diversity. Retrieved from www.ecoshiftconsulting.com/wpcontent/uploads/Potential-Greenhouse-Gas-Emissions-U-S-Federal-FossilFuels.pdf.

O'Loughlin, J., Linke, A. M., \& Witmer, F. D. (2014). Effects of temperature and precipitation variability on the risk of violence in sub-Saharan Africa, 19802012. Proceedings of the National Academy of Sciences, 111, 16712-16717.

Parenti, C. (2013, summer). A radical approach to the climate crisis. Dissent. Retrieved from www.dissentmagazine.org/article/a-radical-approach-to-theclimate-crisis.

Parr, A. (2014). The wrath of capital: Neoliberalism and climate change politics. New York: Columbia University Press.

Pinker, S. (2011). The better angels of our nature: Why violence has declined. New York: Viking.

Raleigh, C. (2010). Political marginalization, climate change, and conflict in African Sahel states. International Studies Review, 12, 69-86.

Raleigh, C., \& Kniveton, D. (2012). Come rain or shine: An analysis of conflict and climate variability in East Africa. Journal of Peace Research, 49, 51-64.

Raleigh, C., Linke, A., \& O'Loughlin, J. (2014). Extreme temperatures and violence. Nature Climate Change, 4(February), 76-77.

Roberts, J. T., \& Parks, B. C. (2006). A climate of injustice: Global inequality, North-South politics, and climate policy. Cambridge, MA: MIT Press.

Rothe, D. L. (2009). State criminality: The crime of all crimes. Lanham, MD: Lexington Books.

Selby, J. (2014). Positivist climate conflict research: A critique. Geopolitics, 19(4), 829-856.

Solnit, R. (2014). The encyclopedia of trouble and spaciousness. San Antonio, TX: Trinity University Press.

Soron, D. (2007). Cruel weather: Natural disasters and structural violence. Transformations, 14, March. Retrieved from www.transformationsjournal. org/journal/issue_14/article_01.shtml.

Stretesky, P. B., Long, M. A., \& Lynch, M. J. (2013). The treadmill of crime: Political economy and green criminology. New York: Routledge. 
Verhoeven, H. (2011). Climate change, conflict and development in Sudan: Global neo-Malthusian narratives and local power struggles. Development and Change, 42(3), 679-707.

Verhoeven, H. (2014). Gardens of Eden or hearts of darkness? The genealogy of discourses on environmental insecurity and climate wars in Africa. Geopolitics, 19, 784-805.

Werrell, C. E., \& Fernia, F. (Eds.). (2013). The Arab spring and climate change. Washington, DC: Center for American Progress, Stimson, \& Center for Climate and Security. Retrieved from climateandsecurity.files.wordpress. com/2012/04/climatechangearabspring-ccs-cap-stimson.pdf.

Wischnath, G., \& Buhaug, H. (2014). On climate variability and civil war in Asia. Climate Change, 122, 709-721. 
This text is taken from Human Ecology Review, Volume 22, Number 2, 2016, published 2016 by ANU Press, The Australian National University, Canberra, Australia. 